\title{
Hereditary Clear Cell Renal Cell
}

\section{Carcinoma}

National Cancer Institute

\section{Source}

National Cancer Institute. Hereditary Clear Cell Renal Cell Carcinoma. NCI Thesaurus.

Code C36260.

A manifestation of von Hippel-Lindau disease or other familial renal cell cancer syndromes that present as a malignant epithelial neoplasm of the kidney. It is characterized by the presence of lipid-containing clear cells within a vascular network. The tumor usually is bilateral and polycentric, and metastasizes to unusual sites. Late metastasis is common. 